\title{
Synthesis of an Oxathiolane Drug Substance Intermediate Guided by Constraint Driven Innovation
}

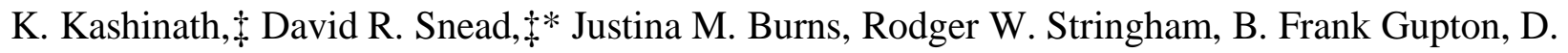
Tyler McQuade*

\section{Supporting Information}

Table of contents

page

Experimental procedures

2

HPLC and Chiral HPLC Chromatograms

8

Copies of ${ }^{1} \mathrm{H},{ }^{13} \mathrm{C}$ NMR spectra

12 


\section{Experimental procedures:}

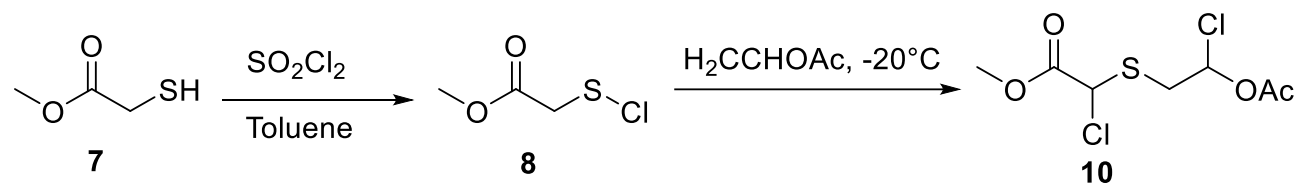

Methyl 2-((2-acetoxy-2-chloroethyl)thio)-2-chloroacetate (10), Screening Procedure: Methyl thioglycolate, $7(50.0 \mathrm{mg}, 42.0 \mu \mathrm{L}, 1 \mathrm{eq})$ was added to an NMR tube in $\mathrm{CDCl}_{3}(500 \mu \mathrm{L})$. The sample was cooled to $-20{ }^{\circ} \mathrm{C}$, and then sulfuryl chloride (136 mg, $79.9 \mu \mathrm{L}, 2.1 \mathrm{eq}$ ) was quickly added and the NMR tube was capped and shaken. The NMR tube warmed to room temperature over the course of 1 hour. NMR showed formation of sulfenyl chloride 8. ${ }^{1} \mathrm{H}$ NMR $(600 \mathrm{MHz}$, $\left.\mathrm{CDCl}_{3}\right): \delta 3.77(\mathrm{~s}, 3 \mathrm{H}), 3.59(\mathrm{~s}, 2 \mathrm{H}) ;{ }^{13} \mathrm{C} \mathrm{NMR}\left(150 \mathrm{MHz}, \mathrm{CDCl}_{3}\right): \delta 169.8,52.7,41.2$. The sulfenyl chloride solution was returned to $-20^{\circ} \mathrm{C}$ and the NMR cap was removed with slight release of pressure. Vinyl acetate $(81.1 \mathrm{mg}, 86.8 \mu \mathrm{L}, 2 \mathrm{eq})$ was added within 5 seconds and the tube was capped and shaken. The reaction was kept at $-20{ }^{\circ} \mathrm{C}$ for 2 hours. Mesitylene $(18.9 \mathrm{mg}, 21.8 \mu \mathrm{L}$, 0.333 equiv.) was added as external standard. NMR showed formation of dichloro compound $\mathbf{1 0 .}$ ${ }^{1} \mathrm{H}$ NMR (600 MHz, $\mathrm{CDCl}_{3}$ ) (mixture of diastereomers): $\delta 6.56(\mathrm{dd}, J=4.1,7.8 \mathrm{~Hz}, 1 \mathrm{H}), 6.50$ (dd, $J=5.1,7.3 \mathrm{~Hz}, 1 \mathrm{H}), 5.43(\mathrm{~d}, J=12.7 \mathrm{~Hz}, 1 \mathrm{H}), 3.82(\mathrm{~d}, J=2.4 \mathrm{~Hz}, 3 \mathrm{H}), 3.49-3.29(\mathrm{~m}, 2 \mathrm{H}), 2.12$ $(\mathrm{d}, J=1.10 \mathrm{~Hz}, 3 \mathrm{H}) ;{ }^{13} \mathrm{C} \mathrm{NMR}\left(150 \mathrm{MHz}, \mathrm{CDCl}_{3}\right.$ ) (mixture of diastereomers): $\delta 168.2,166.6$, $81.3,81.2,60.6,60.1,53.8,53.8,37.5,37.2,20.7$.

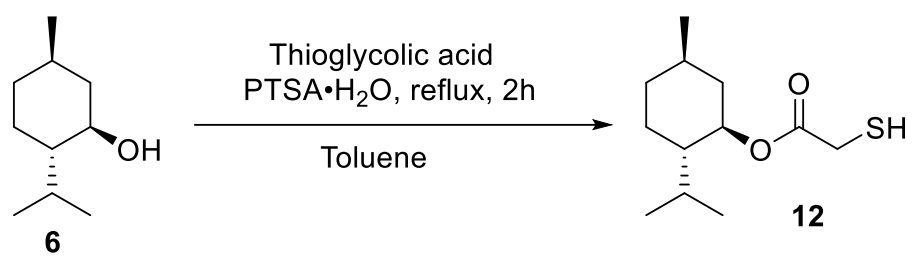

$(1 R, 2 S, 5 R)$-2-Isopropyl-5-methylcyclohexyl 2-mercaptoacetate (12): L-Menthol, 6 (210g, 1.34 mol), thioglycolic acid $(98.5 \mathrm{~mL}, 1.41 \mathrm{mmol})$ and PTSA $\cdot \mathrm{H}_{2} \mathrm{O}(5.11 \mathrm{~g}, 26.9 \mathrm{mmol})$ were taken up in toluene $(105 \mathrm{~mL})$ and heated under reflux with azeotropic removal of water for $2 \mathrm{~h}$. The reaction mixture was cooled to room temperature, $1 \% \mathrm{NaOH}(100 \mathrm{~mL})$ was added and stirred for $5 \mathrm{~min}$. The organic layer was separated and concentrated under reduced pressure to afford compound 12 (304 g, 98\%); ${ }^{1} \mathrm{H}$ NMR (600 MHz, $\left.\mathrm{CDCl}_{3}\right): \delta 4.70(\mathrm{dt}, J=4.4,10.9 \mathrm{~Hz}, 1 \mathrm{H}), 3.22(\mathrm{~d}, J=8.4 \mathrm{~Hz}$, 2H), 2.01 - 1.97 (m, 2H), 1.91-1.88 (m, 1H), 1.69 - $1.66(\mathrm{~m}, 2 \mathrm{H}), 1.50-1.47$ (m, 1H), 1.41 - 1.37 
$(\mathrm{m}, 1 \mathrm{H}), 1.12-0.96(\mathrm{~m}, 2 \mathrm{H}), 0.91-0.86(\mathrm{~m}, 7 \mathrm{H}), 0.76(\mathrm{~d}, J=7.0 \mathrm{~Hz}, 3 \mathrm{H}) ;{ }^{13} \mathrm{C} \mathrm{NMR}(150 \mathrm{MHz}$, $\left.\mathrm{CDCl}_{3}\right): \delta 170.5,77.3,47.0,40.6,34.2,31.4,26.8,26.2,23.4,22.0,20.8,16.3$; MS: 272 $(\mathrm{M}+\mathrm{ACN}+\mathrm{H})^{+}$; Spectral data was compared with reported values and found to be identical. ${ }^{1}$

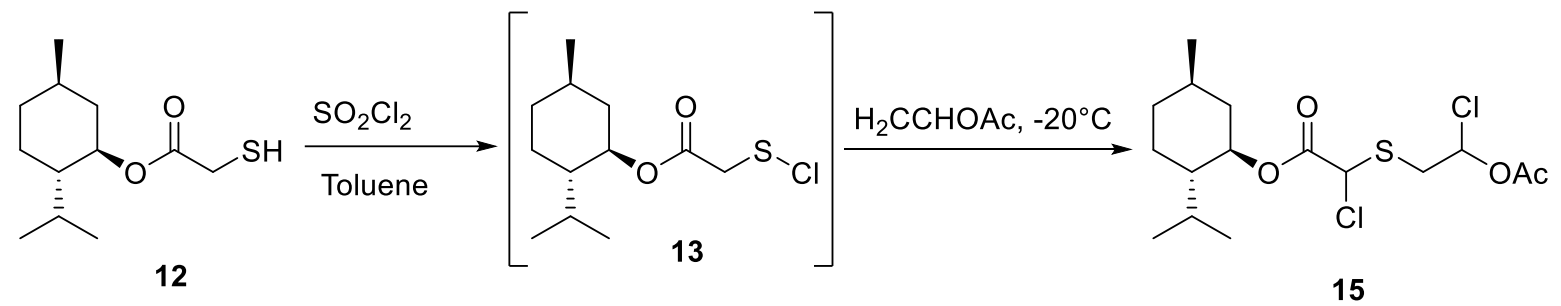

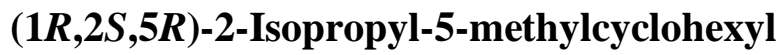

2-((2-acetoxy-2-chloroethyl)thio)-2-

chloroacetate (15): To a stirred solution of compound 12 (10 g, $43.4 \mathrm{mmol})$ in toluene (50 mL), sulfuryl chloride $(7.72 \mathrm{~mL}, 95.5 \mathrm{mmol})$ was added drop wise for $10 \mathrm{~min}$ at $-20{ }^{\circ} \mathrm{C}$ and stirred for 3 h. ${ }^{1} \mathrm{H}$ NMR showed formation of sulfenyl chloride $13 .{ }^{1} \mathrm{H}$ NMR $\left(600 \mathrm{MHz}, \mathrm{CDCl}_{3}\right): \delta 4.79$ (dt, $J=4.4,10.9 \mathrm{~Hz}, 1 \mathrm{H}), 3.89$ (s, 2H), $2.09-2.00$ (m, 1H), 1.93 (dt, $J=2.8,7.0 \mathrm{~Hz}, 1 \mathrm{H}), 1.77$ - 1.64 $(\mathrm{m}, 2 \mathrm{H}), 1.56-1.38(\mathrm{~m}, 2 \mathrm{H}), 1.18-1.01(\mathrm{~m}, 2 \mathrm{H}), 0.95-0.84(\mathrm{~m}, 7 \mathrm{H}), 0.80-0.73(\mathrm{~m}, 3 \mathrm{H}) ;{ }^{13} \mathrm{C}$ NMR (150 MHz, $\left.\mathrm{CDCl}_{3}\right): \delta$ 167.4, 76.5, 46.9, 43.3, 40.7, 34.1, 31.4, 26.1, 23.2, 22.0, 20.7, 16.2. Then, vinyl acetate $(8 \mathrm{~mL}, 86.8 \mathrm{mmol})$ was added drop wise for $10 \mathrm{~min}$ at $-20{ }^{\circ} \mathrm{C}$ and stirred for another $3 \mathrm{~h}$. Then, the reaction mixture was quenched with $1 \mathrm{M} \mathrm{NaHCO}_{3}(100 \mathrm{~mL})$ and organic layer was separated and extracted with toluene $(50 \mathrm{~mL})$. The combined organic fractions were dried over sodium sulfate and concentrated under reduced pressure. The crude compound was purified by column chromatography using 3\% EtOAc in hexanes to afford desired compound 15 as a colorless oil. ${ }^{1} \mathrm{H} \mathrm{NMR}\left(600 \mathrm{MHz}, \mathrm{CDCl}_{3}\right)$ (mixture of diastereomers): $\delta 6.59-6.52(\mathrm{~m}, 1 \mathrm{H})$, $5.41-5.36(\mathrm{~m}, 1 \mathrm{H}), 4.74(\mathrm{dt}, J=4.0,11.0 \mathrm{~Hz}, 1 \mathrm{H}), 3.49-3.43(\mathrm{~m}, 1 \mathrm{H}), 3.36-3.31(\mathrm{~m}, 1 \mathrm{H}), 2.14$ (bs, 3H), 2.03 - $1.99(\mathrm{~m}, 1 \mathrm{H}), 1.93-1.88(\mathrm{~m}, 1 \mathrm{H}), 1.69$ (d, J=11.4 Hz, 2H), 1.49 - 1.43 (m, 2H), 1.08 - $1.01(\mathrm{~m}, 2 \mathrm{H}), 0.92-0.86(\mathrm{~m}, 7 \mathrm{H}), 0.77-0.75(\mathrm{~m}, 3 \mathrm{H}) ;{ }^{13} \mathrm{C} \mathrm{NMR}\left(150 \mathrm{MHz}, \mathrm{CDCl}_{3}\right)$ (mixture of diastereomers): $\delta$ 168.1, 168.1, 165.6, 165.5, 81.6, 81.5, 81.4, 81.3, 77.6, 77.5, 77.5, 61.7, 61.6, 61.0, 60.7, 47.0, 47.0, 46.9, 40.4, 40.3, 40.1, 37.6, 37.5, 37.5, 37.4, 34.0, 31.4, 31.4, 26.1, 26.1, 26.1, 23.3, 23.2, 21.9, 20.7, 20.7, 16.1; MS: $349(\mathrm{M}-\mathrm{HCl})^{+}$; HRMS calculated for $\mathrm{C}_{14} \mathrm{H}_{20} \mathrm{O}_{4} \mathrm{~N}$ $[\mathrm{M}+\mathrm{H}]^{+}:$385.1007, found 385.1010. 


\section{General procedure for the cyclization:}
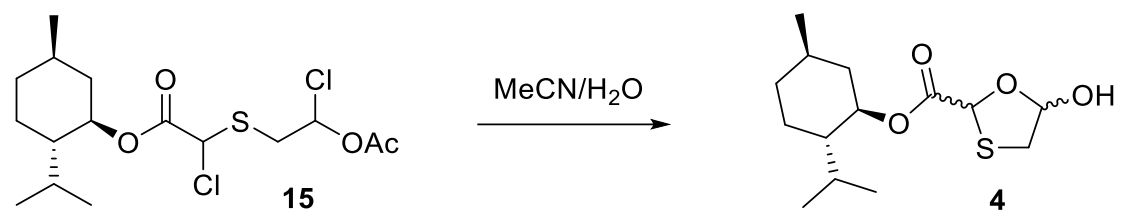

$(1 R, 2 S, 5 R)$-2-Isopropyl-5-methylcyclohexyl 5-hydroxy-1,3-oxathiolane-2-carboxylate: To a stirred solution of compound 15 (1 eq) in acetonitrile (20 vol) and water (20 vol), additive (2 eq) was added and heated at the temperature as mentioned in Table 2 in manuscript. The reaction was monitored by TLC, and after consumption of starting material the reaction mixture was cooled to room temperature and extracted with ethyl acetate. The organic fraction was dried over sodium sulfate and concentrated under reduced pressure. The crude compound was purified by column chromatography or precipitated from hexanes to afford compound 4.

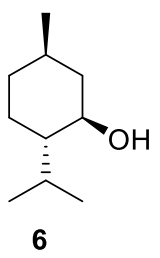

6
1) Thioglycolic acid, toluene

2) $\mathrm{SO}_{2} \mathrm{Cl}_{2}, 0^{\circ} \mathrm{C}$

3) Vinylacetate, $-20^{\circ} \mathrm{C}$

4) $\mathrm{H}_{2} \mathrm{O}, \mathrm{MeCN}, 1 \mathrm{M} \mathrm{NaHCO}, 70^{\circ} \mathrm{C}$

5) $1 \%$ TEA in Hexanes, 0 to $-15^{\circ} \mathrm{C}$

$56 \%$ Overall

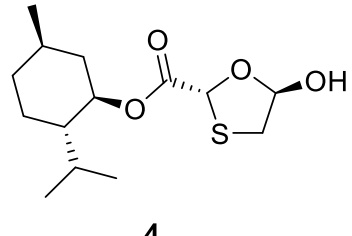

(2R,5R)-5-hydroxy-1,3-oxathiolane-2-

$(1 R, 2 S, 5 R)$-2-Isopropyl-5-methylcyclohexyl carboxylate (4): L-Menthol, 6 (10.0 g, $64 \mathrm{mmol})$, PTSA. $\mathrm{H}_{2} \mathrm{O}$ (243 mg, 1.3mmol), and thioglycolic acid $(4.7 \mathrm{~mL}, 67.2 \mathrm{mmol})$ were taken up in toluene $(50 \mathrm{~mL})$ and heated at reflux with azeotropic removal of water for $2 \mathrm{~h}$. Then, the reaction mixture was cooled to $0^{\circ} \mathrm{C}$, sulfuryl chloride $(11.4 \mathrm{~mL}, 141 \mathrm{mmol}$ ) was added in a rate of $0.76 \mathrm{~mL} / \mathrm{min}$ over $15 \mathrm{~min}$ using a syringe pump, and stirred for $1 \mathrm{~h}$ at the same temperature. The mixture was then warmed to room temperature with continued stirring for $2 \mathrm{~h}$. The reaction mixture became yellow in color indicating formation of sulfenyl chloride 13. The reaction mixture was cooled to $-20{ }^{\circ} \mathrm{C}$ again, and vinyl acetate $(11.8 \mathrm{~mL}$, $128 \mathrm{mmol}$ ) was added at a rate of $0.786 \mathrm{~mL} / \mathrm{min}$ over $15 \mathrm{~min}$ using a syringe pump. Stirring was continued for an additional $3 \mathrm{~h}$, and then the mixture was allowed to warm to $0{ }^{\circ} \mathrm{C}$. The reaction was quenched using $1 \mathrm{M} \mathrm{NaHCO}_{3}(100 \mathrm{~mL})$ and extracted with toluene $(30 \mathrm{~mL})$. It is important not to reach alkaline $\mathrm{pH}$ as base rapidly decomposes starting material and product. The combined organic fractions were dried over sodium sulfate and concentrated in vacuo to afford dichloro compound $15(25.4 \mathrm{~g})$ as a colorless oil. The crude compound $\mathbf{1 5}(25.4 \mathrm{~g})$ was taken up in ACN 
$(400 \mathrm{~mL})$ and water $(400 \mathrm{~mL})$ and the reaction mixture was heated until the internal temperature reached $70{ }^{\circ} \mathrm{C}$, typically over the course of 40 minutes. Once the temperature reached $70{ }^{\circ} \mathrm{C}, 1 \mathrm{M}$ $\mathrm{NaHCO}_{3}(128 \mathrm{~mL})$ was added over $2.5 \mathrm{~h}$ using a syringe pump at a flow rate of $0.85 \mathrm{~mL} / \mathrm{min}$. Toluene $(100 \mathrm{~mL})$ was added to the reaction mixture and the organic and aqueous layers were separated. The organic layer was dried over sodium sulfate and concentrated using a rotary evaporator and the residue was cooled to $0{ }^{\circ} \mathrm{C}$. A solution of $1 \%$ triethylamine in hexanes $(60 \mathrm{~mL})$ was added dropwise over $30 \mathrm{~min}$ and stirred for an additional $2 \mathrm{~h}$ at the same temperature. Solid precipitation was observed. The suspension was stored in a freezer overnight. The solid was filtered using a Büchner Funnel, washed with cold hexanes $(40 \mathrm{~mL})$, and dried. Compound 4 was obtained as a white solid $\left(10.41 \mathrm{~g}, 56 \%\right.$,). HPLC purity $99.3 \% .{ }^{1} \mathrm{H}$ NMR $\left(600 \mathrm{MHz}, \mathrm{CDCl}_{3}\right): \delta$ 6.00 - $5.90(\mathrm{~m}, 1 \mathrm{H}), 5.57$ - $5.54(\mathrm{~m}, 1 \mathrm{H}), 4.74$ - $4.70(\mathrm{~m}, 1 \mathrm{H}), 3.30$ - $3.28(\mathrm{~m}, 1 \mathrm{H}), 3.15-3.04(\mathrm{~m}$, 1H), 2.02 - $1.94(\mathrm{~m}, 2 \mathrm{H}), 1.70$ - $1.67(\mathrm{~m}, 2 \mathrm{H}), 1.50$ - 1.41 (m, 2H), 1.06 - 0.98 (m, 2H), 0.93 - 0.86 $(\mathrm{m}, 7 \mathrm{H}), 0.77-0.75(\mathrm{~m}, 3 \mathrm{H}) ;{ }^{13} \mathrm{C}$ NMR $\left(150 \mathrm{MHz}, \mathrm{CDCl}_{3}\right): \delta 172.4,169.3,103.2,103.2,101.1$, 80.2, 80.2, 78.1, 76.0, 47.1, 47.0, 40.7, 40.4, 40.3, 38.5, 34.1, 34.1, 31.4, 31.4, 26.0, 23.3, 23.3, 23.2, 22.0, 22.0, 20.8, 20.7, 16.2, 16.1, 16.1. MS: $311(\mathrm{M}+\mathrm{Na})^{+}$. Spectral data, HPLC data was compared with commercial sample purchased from combiblocks (catlog no AM2217) and found to be identical. (Figure S1 \& S2). (Note: It was observed that Compound 4 epimerizes in NMR solvent)
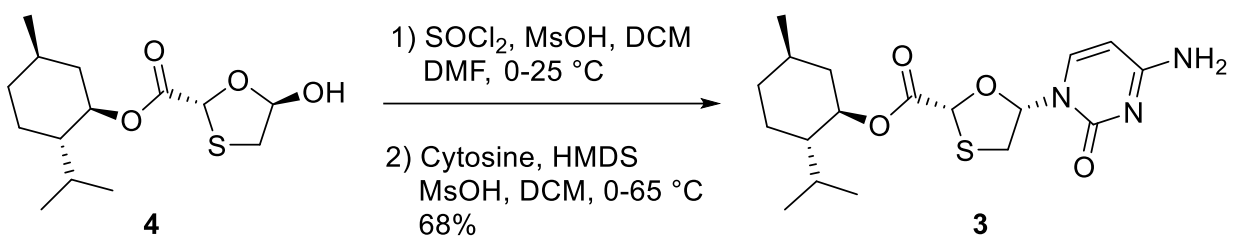

(1R,2S,5R)-2-Isopropyl-5-methylcyclohexyl (2R,5S)-5-(4-amino-2-oxopyrimidin-1(2H)-yl)1,3-oxathiolane-2-carboxylate (3): (a) To a solution of compound 4 (1g, $3.47 \mathrm{mmol})$ in dichloromethane $(10 \mathrm{~mL})$, methanesulphonic acid $(2.2 \mu \mathrm{L})$ and dimethylformamide $(282 \mu \mathrm{L})$ were added and cooled to $0{ }^{\circ} \mathrm{C}$. Then, thionyl chloride $(264 \mu \mathrm{L})$ was added and the reaction mixture was stirred for 1h. (b) A suspension of cytosine (385 mg, 3.47mmol), methanesulphonic acid (2.2 $\mu \mathrm{L})$ and hexamethyldisilazane $(800 \mu \mathrm{L}, 3.81 \mathrm{mmol})$ was heated in toluene $(2 \mathrm{~mL})$ at reflux until a clear solution was obtained $\sim$ h. The solution of silylcytosine was treated with triethylamine (483 $\mu \mathrm{L}$ ). The solution of (a) was added to solution of (b) maintaining a gentle reflux, the resulting mixture was heated at reflux for $4 \mathrm{~h}$. Then, to the reaction mixture triethylamine $(240 \mu \mathrm{L})$ and 
water $(2 \mathrm{~mL})$ were added and stirred for $1 \mathrm{~h}$ at room temperature followed by addition of hexanes $(5 \mathrm{~mL})$ which was added and then stirred overnight. Solid precipitated from solution. The solid was filtered, washed with water $(5 \mathrm{~mL})$ and isopropyl acetate $(10 \mathrm{~mL})$, and dried in vacuo to afford compound 3 as an off-white solid $(0.9 \mathrm{~g}, 68 \%) .{ }^{1} \mathrm{H}$ NMR $\left(600 \mathrm{MHz}, \mathrm{DMSO}-\mathrm{d}_{6}\right) \delta 7.94(\mathrm{~d}, J=7.3$ Hz, 1H), 7.31 (brs., 1H), 7.27 (brs., 1H), 6.33 (t, J=5.8 Hz, 1H), 5.82 - 5.71 (m, 1H), 5.67 (s, 1H), $4.66(\mathrm{~d}, J=4.2 \mathrm{~Hz}, 1 \mathrm{H}), 3.52(\mathrm{dd}, J=4.9,11.8 \mathrm{~Hz}, 1 \mathrm{H}), 3.11(\mathrm{dd}, J=6.6,11.9 \mathrm{~Hz}, 1 \mathrm{H}), 2.03$ $1.86(\mathrm{~m}, 2 \mathrm{H}), 1.64$ (d, $J=11.0 \mathrm{~Hz}, 2 \mathrm{H}), 1.47$ (d, $J=3.3 \mathrm{~Hz}, 1 \mathrm{H}), 1.40$ (brs., $1 \mathrm{H}), 1.03$ (t, $J=11.6$ $\mathrm{Hz}, 2 \mathrm{H}), 0.87(\mathrm{dd}, J=6.9,11.8 \mathrm{~Hz}, 7 \mathrm{H}), 0.72(\mathrm{~d}, J=6.8 \mathrm{~Hz}, 3 \mathrm{H}) ;{ }^{13} \mathrm{C}$ NMR $(150 \mathrm{MHz}$, DMSO$\left.\mathrm{d}_{6}\right) \delta 169.6,166.1,155.1,140.9,94.8,89.2,77.8,75.9,46.8,40.6,35.7,34.0,31.3,26.2,23.3$, 22.3, 21.0, 16.5. MS: $382(\mathrm{M}+\mathrm{H})^{+}$. Spectral data was compared with reported values and found to be identical. ${ }^{2}$

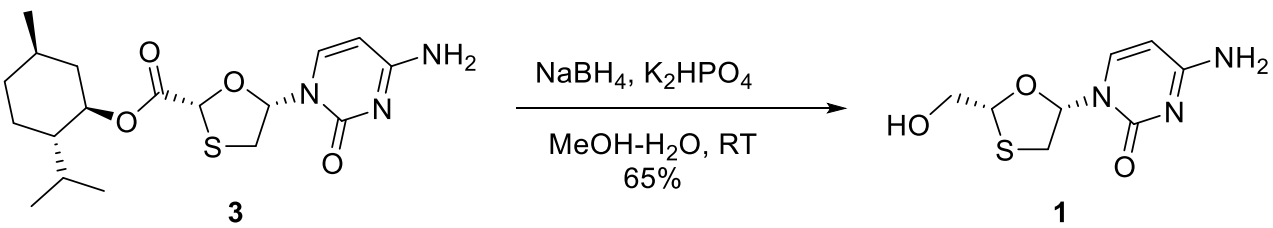

4-Amino-1-((2R,5S)-2-(hydroxymethyl)-1,3-oxathiolan-5-yl)pyrimidin-2(1H)-one (1): To a solution of compound $3(0.5 \mathrm{~g}, 1.3 \mathrm{mmol})$ in methanol and water (3:2), $\mathrm{K}_{2} \mathrm{HPO}_{4}(680 \mathrm{mg}, 3.9$ mmol) in water $(25 \mathrm{~mL})$ was added at room temperature. After 15 min a solution of $\mathrm{NaBH}_{4}(99$ $\mathrm{mg}, 2.6 \mathrm{mmol})$ in water $(1 \mathrm{~mL})$ containing $25 \% \mathrm{w} / \mathrm{w} \mathrm{NaOH}$ solution $(10 \mu \mathrm{L})$ was added to the reaction mixture. Then the reaction mixture stirred for $5 \mathrm{~h}$ at the same temperature, monitoring the progress of the reaction by TLC (10\% $\mathrm{MeOH}$ in DCM). After complete consumption of starting material, the reaction was quenched with $\mathrm{HCl}$, adjusted to $\mathrm{pH}$ of $4-4.5$, and washed with diethyl ether to remove the menthol. The aqueous layer $\mathrm{pH}$ was adjusted to 7-7.2 using $2 \mathrm{M} \mathrm{NaOH}$ solution, and the mixture was filtered and concentrated under the reduced pressure. The crude compound was purified by recrystallization using hexane: EtOAc: methanol (2:2:1) to afford lamivudine 1 (195 mg, 65\%). ${ }^{1} \mathrm{H}$ NMR (600 MHz, Methanol-d 4$) \delta 8.05(\mathrm{~d}, J=7.5 \mathrm{~Hz}, 1 \mathrm{H}), 6.28$ $(\mathrm{dd}, J=4.5,5.2 \mathrm{~Hz}, 1 \mathrm{H}), 5.87(\mathrm{~d}, J=7.5 \mathrm{~Hz}, 1 \mathrm{H}), 5.26(\mathrm{t}, J=3.9 \mathrm{~Hz}, 1 \mathrm{H}), 3.93(\mathrm{dd}, J=3.5,12.5$ $\mathrm{Hz}, 1 \mathrm{H}), 3.86(\mathrm{dd}, J=4.2,12.5 \mathrm{~Hz}, 1 \mathrm{H}), 3.50(\mathrm{dd}, J=5.4,12.0 \mathrm{~Hz}, 1 \mathrm{H}), 3.12$ (dd, $J=4.4,11.9$ $\mathrm{Hz}, 1 \mathrm{H}) ;{ }^{13} \mathrm{C}$ NMR (150 MHz, Methanol-d 4$) \delta 166.3,156.5,141.4,94.3,87.4,86.6,62.6,37.1$; MS: $230(\mathrm{M}+\mathrm{H})^{+}$. Spectral data was compared with reported values and found to be identical. ${ }^{2}$ 
HPLC (Figure S3 \& S4) and chiral HPLC (Figure S5 \& S6) of standard and synthesized were compared and found to be identical.
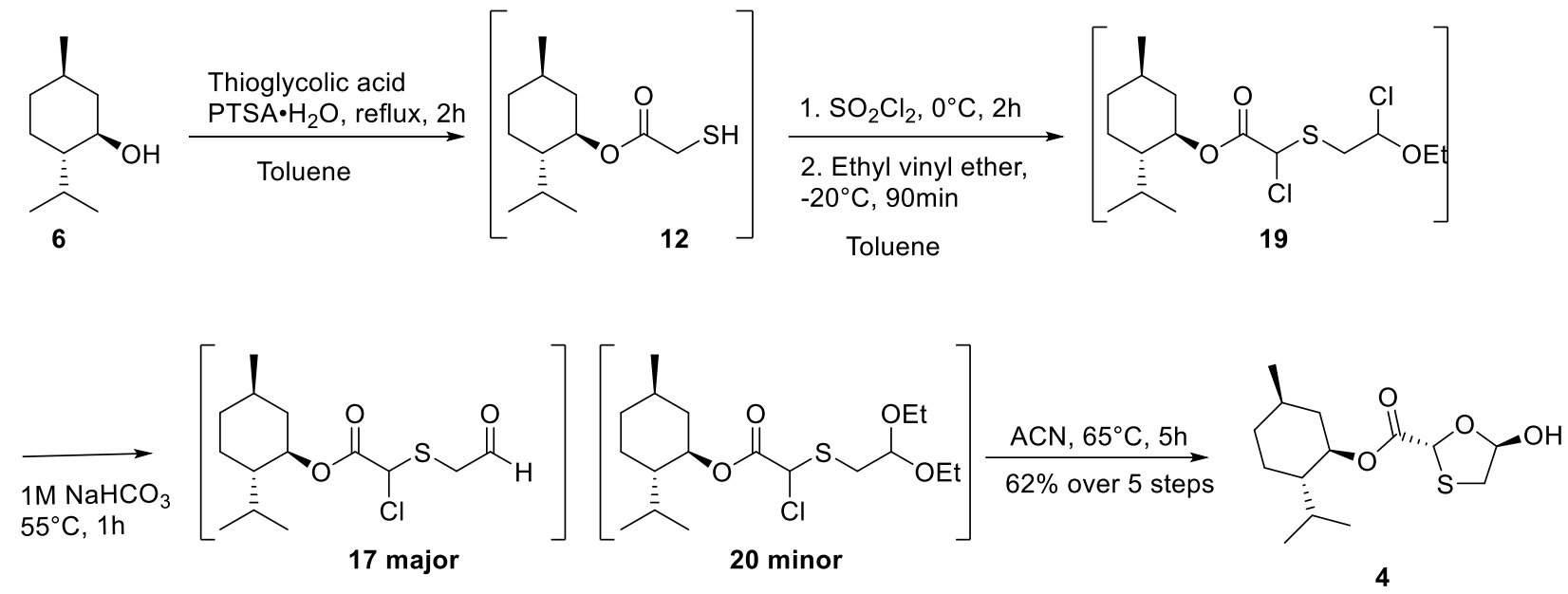

(1R,2S,5R)-2-Isopropyl-5-methylcyclohexyl 5-hydroxy-1,3-oxathiolane-2-carboxylate (4): A mixture of menthol 6 (5 g, $32 \mathrm{mmol})$, thioglycolic acid $(2.3 \mathrm{~mL}, 34 \mathrm{mmol}), \mathrm{PTSA} \cdot \mathrm{H}_{2} \mathrm{O}(120 \mathrm{mg}$, $0.64 \mathrm{mmol})$ in toluene $(25 \mathrm{~mL})$ was heated at reflux with azeotropic removal of water for $2 \mathrm{~h}$. The reaction mixture was cooled to $0{ }^{\circ} \mathrm{C}$, and sulfuryl chloride $(5.7 \mathrm{~mL}, 70 \mathrm{mmol})$ was added over the period of $10 \mathrm{~min}$. The reaction was stirred for $2 \mathrm{~h}$ while allowing the reaction mixture to warm to room temperature. After this time, the mixture was cooled to $-20{ }^{\circ} \mathrm{C}$ and ethyl vinyl ether $(6.1 \mathrm{~mL}$, $64 \mathrm{mmol}$ ) was added over the period of $10 \mathrm{~min}$. The reaction mixture was stirred at same temperature for $90 \mathrm{~min}$. Monitoring the reaction by NMR showed the formation of dichloro ether compound 19. ${ }^{1} \mathrm{H} \mathrm{NMR}\left(600 \mathrm{MHz}, \mathrm{CDCl}_{3}\right)$ (mixture of diastereomers): $\delta 5.80-5.67(\mathrm{~m}, 1 \mathrm{H}), 5.62$ $(\mathrm{d}, J=7.0 \mathrm{~Hz}, 1 \mathrm{H}), 4.78-4.68(\mathrm{~m}, 1 \mathrm{H}), 4.04-3.91(\mathrm{~m}, 1 \mathrm{H}), 3.66-3.52(\mathrm{~m}, 1 \mathrm{H}), 3.50$ - $3.30(\mathrm{~m}$, 1H), 3.22 (dd, $J=3.1,14.7 \mathrm{~Hz}, 1 \mathrm{H}), 2.08-1.97(\mathrm{~m}, 1 \mathrm{H}), 1.92$ (dd, $J=2.1,4.8 \mathrm{~Hz}, 1 \mathrm{H}), 1.69$ (d, $J$ $=12.3 \mathrm{~Hz}, 2 \mathrm{H}), 1.55-1.43(\mathrm{~m}, 2 \mathrm{H}), 1.34-1.22(\mathrm{~m}, 3 \mathrm{H}), 1.11-0.99(\mathrm{~m}, 2 \mathrm{H}), 0.97-0.80(\mathrm{~m}, 8 \mathrm{H})$, $0.76(\mathrm{~d}, J=7.0 \mathrm{~Hz}, 3 \mathrm{H}) ;{ }^{13} \mathrm{C} \mathrm{NMR}\left(150 \mathrm{MHz}, \mathrm{CDCl}_{3}\right)$ (mixture of diastereomers): $\delta 165.8,165.8$, 96.5, 96.2, 96.1, 67.0, 66.8, 62.8, 62.7, 61.4, 61.2, 47.0, 47.0, 46.9, 40.4, 40.3, 40.2, 40.2, 39.2, 39.1, 38.6, 38.5, 34.1, 31.4, 31.4, 31.4, 26.1, 26.0, 23.3, 23.3, 23.2, 22.0, 20.7, 20.7, 16.2, 16.1, $14.3,14.3$. The reaction mixture was quenched with $1 \mathrm{M} \mathrm{NaHCO}_{3}(50 \mathrm{~mL})$ and heated at $50{ }^{\circ} \mathrm{C}$ for 1h. ${ }^{1} \mathrm{H}$ NMR showed formation of aldehyde 17 (major) and diethylacetal 20 (minor) mixture. Acetonitrile $(50 \mathrm{~mL})$ was added to the reaction mixture and heated at $65^{\circ} \mathrm{C}$ for $5 \mathrm{~h} .{ }^{1} \mathrm{HNMR}$ showed formation of target compound 4. The reaction mixture was cooled to room temperature, and the organic layer was separated and concentrated. The residue was cooled to $0{ }^{\circ} \mathrm{C}$, a solution of $1 \%$ 
triethylamine in hexanes $(40 \mathrm{~mL})$ was added dropwise over $30 \mathrm{~min}$, and the mixture was stirred for an additional $2 \mathrm{~h}$ at the same temperature. Solid precipitation was observed. The suspension was stored in a freezer overnight. The solid was filtered using a Büchner Funnel, washed with cold hexanes (40 mL), and dried. Compound 4 was obtained as a white solid $(5.7 \mathrm{~g}, 62 \%)$. NMR purity 98\%. Spectral data and purity were compared with the compound 4 from vinyl acetate route and found to be identical.

\section{HPLC Analysis}

HPLC analysis was accomplished using method described below

\begin{tabular}{|c|c|}
\hline Mobile Phase A & $\begin{array}{c}\text { 15\%: } 2.5 \mathrm{mM} \text { Ammonium Formate in } 18 \mathrm{M} \Omega \text { Water, } \mathrm{pH} \\
\text { Mobile Phase B }\end{array}$ \\
\hline Flowrate & $1.12 \mathrm{~mL} / \mathrm{min}$ \\
\hline Column Compartment Temperature & $10 \circ \mathrm{C}$ \\
\hline Column & Zorbax Eclipse XDB-C18 $4.6 \times 250 \mathrm{~mm}, 5 \mu \mathrm{m}$ \\
\hline Runtime & $10 \mathrm{~min}$ \\
\hline Injection Volume & $10 \mu \mathrm{L}$ \\
\hline Monitored Wavelengths $(\mathbf{n m})$ & 210,260 \\
\hline
\end{tabular}

\section{HPLC Chromatograms of compound 4}

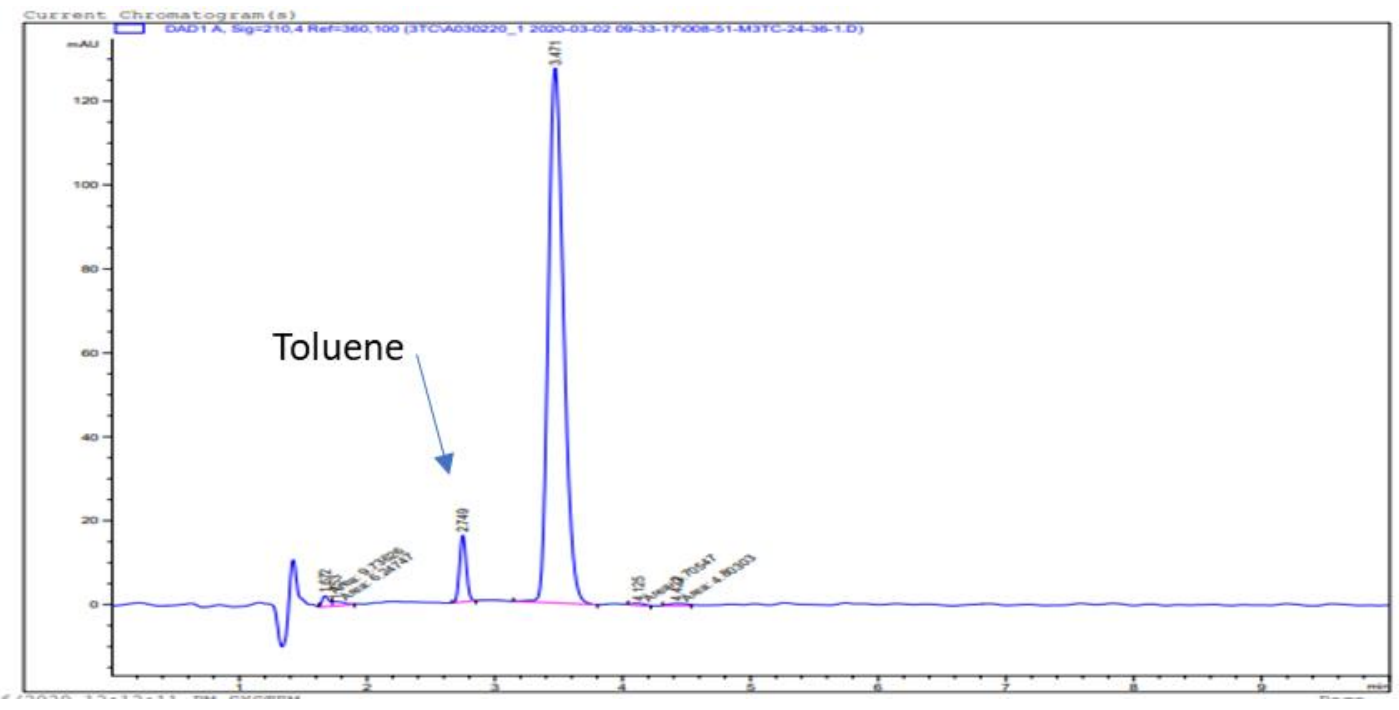

Figure S1. HPLC-DAD Chromatogram for Compound 4 (Synthesized from Vinyl Acetate) 


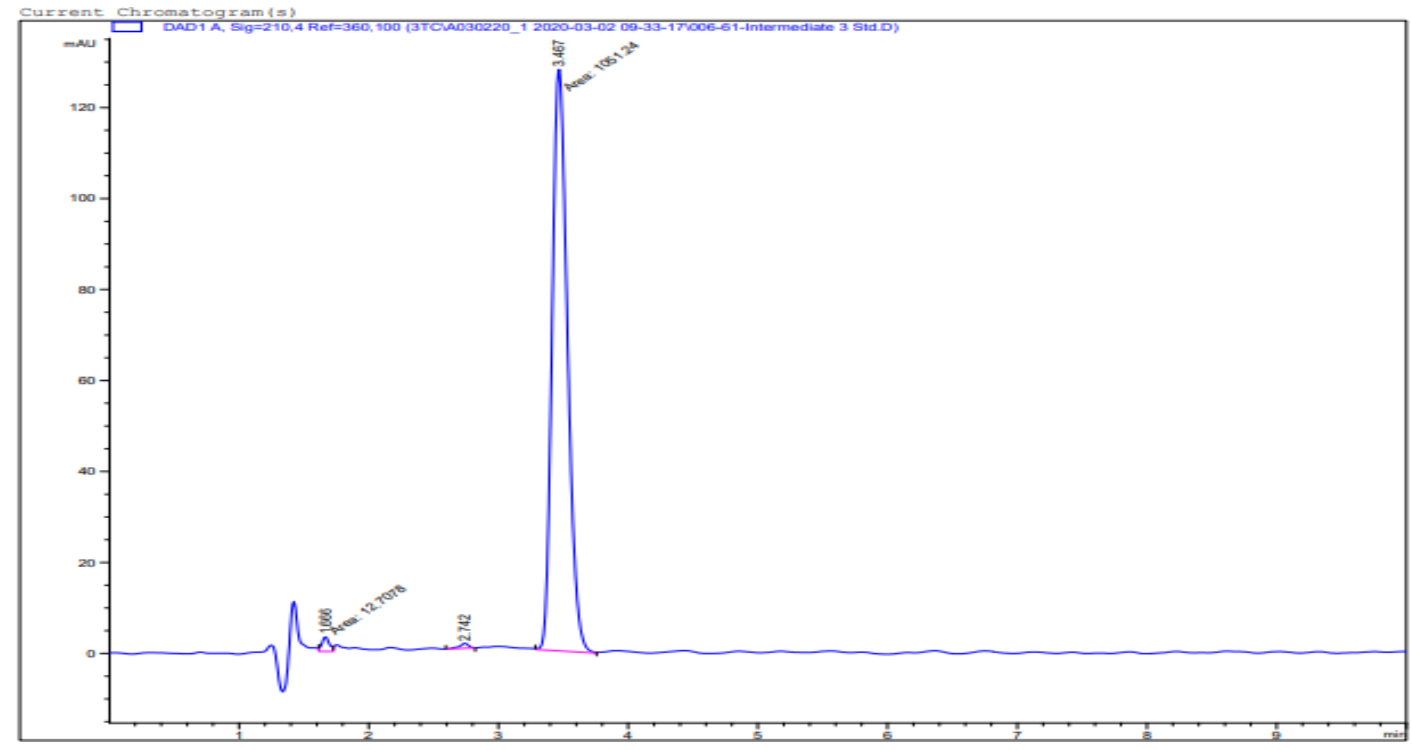

Figure S2. HPLC-DAD Chromatogram for Compound 4 (Commercial Sample)

\section{HPLC Chromatograms of Lamivudine 1.}

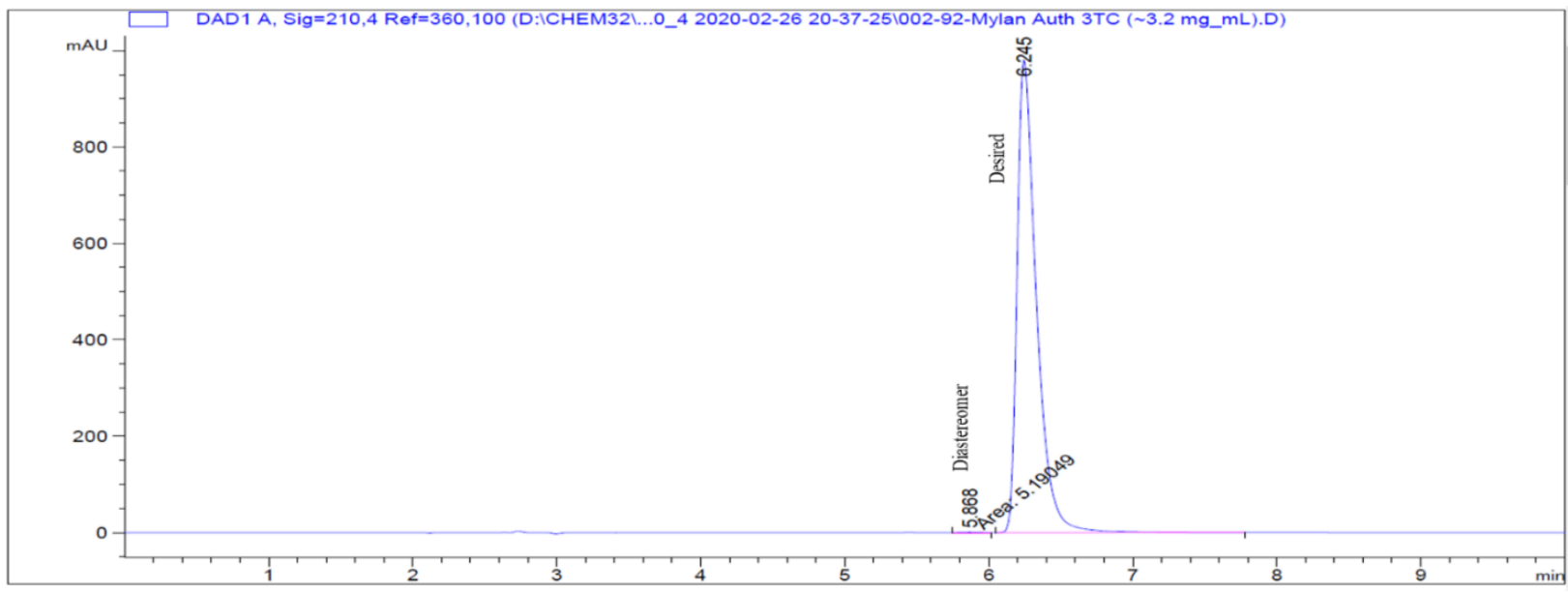

Figure S3. LC-DAD Chromatogram for Standard Lamivudine 1 


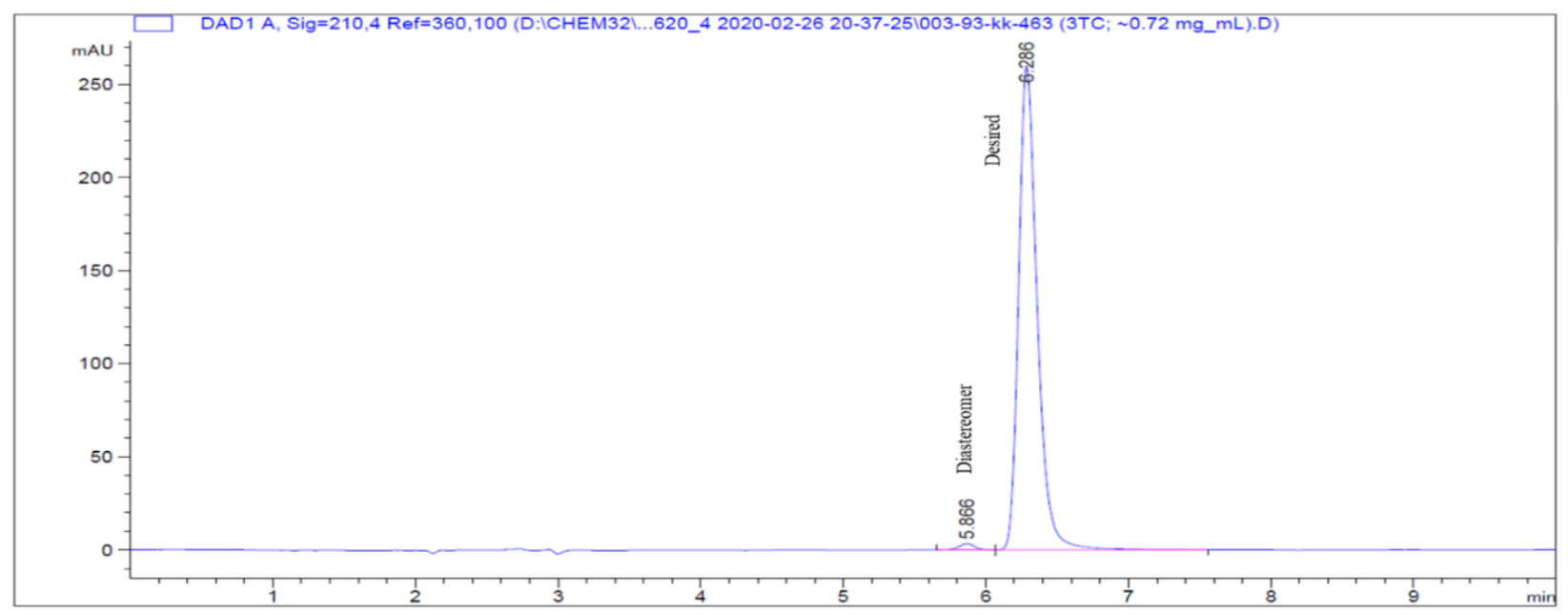

Figure S4. LC-DAD Chromatogram for Lamivudine 1 from Vinyl Acetate

\section{HPLC Results:}

\begin{tabular}{|c|c|c|c|}
\hline ID & $\begin{array}{c}\text { Area \% @ 210 nm for } \\
\text { desired peak }\end{array}$ & $\begin{array}{c}\text { Area \% @ 210 nm for } \\
\text { diastereomer peak }\end{array}$ & $\begin{array}{c}\text { Peak Area \% for } \\
\text { desired @ 260 nn }\end{array}$ \\
\hline $\begin{array}{c}\text { Lamivudine } \\
\text { standard }\end{array}$ & $99.94 \%$ & $0.06 \%$ & $99.803 \%$ \\
\hline $\begin{array}{c}\text { Lamivudine 1 } \\
\text { synthesized }\end{array}$ & $98.90 \%$ & $1.10 \%$ & $98.670 \%$ \\
\hline
\end{tabular}

\section{Chiral Analysis}

Chiral analysis was accomplished using the chiral SFC method described below.

\begin{tabular}{|c|c|}
\hline Mobile Phase A & $80 \%: \mathrm{CO}_{2}$ \\
\hline Mobile Phase B & $20 \%: \mathrm{EtOH}$ \\
\hline Flowrate & $2 \mathrm{~mL} / \mathrm{min}$ \\
\hline Column & ChiralPak IG $4.6 \times 100 \mathrm{~mm}, 5 \mu \mathrm{m}$ \\
\hline Runtime & $15 \mathrm{~min}$ \\
\hline Injection Volume & $10 \mu \mathrm{L}$ \\
\hline Monitored Wavelengths $(\mathbf{n m})$ & 210,260 \\
\hline
\end{tabular}




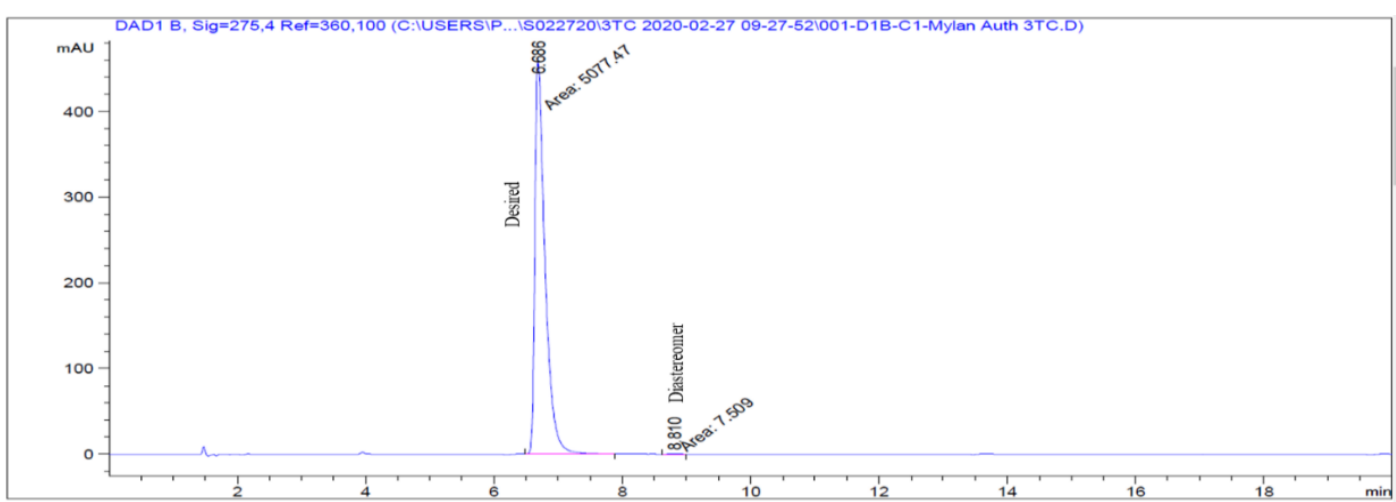

Figure S5. Chiral Chromatogram for Standard Lamivudine 1.

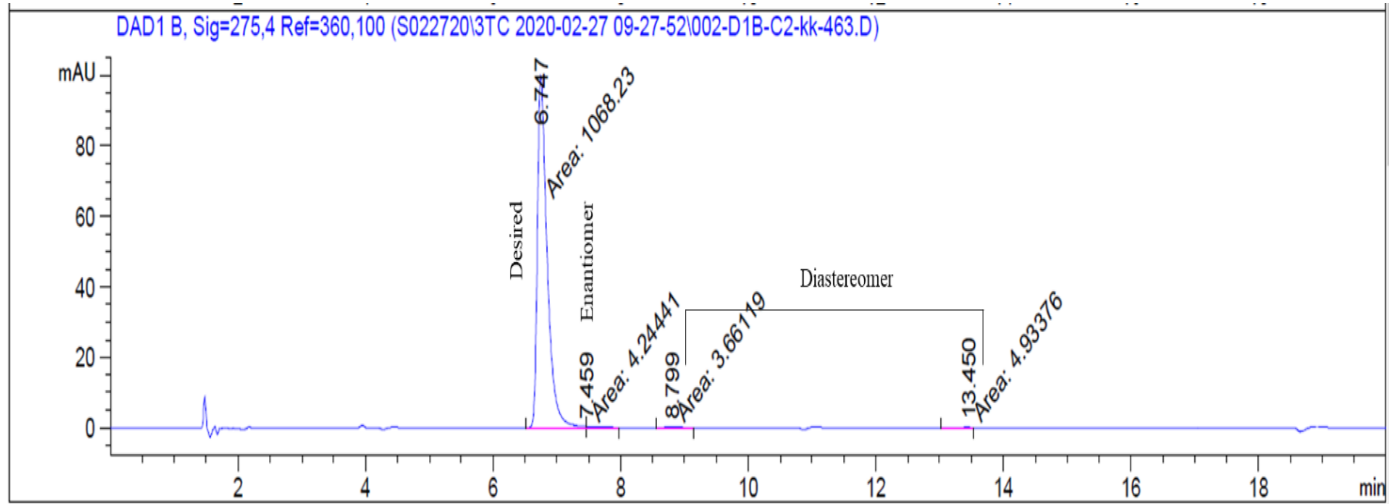

Figure S6. Chiral Chromatogram for Lamivudine 1 from Vinyl Acetate

SFC Results (Chiral)

\begin{tabular}{|c|c|c|c|c|}
\hline ID & $\begin{array}{c}\text { Area \% @ 210 nm } \\
\text { for desired peak }\end{array}$ & $\begin{array}{c}\text { Area \% @ 210 } \\
\text { nm for } \\
\text { enantiomer peak }\end{array}$ & $\begin{array}{c}\text { Area \% @ 210 nm for } \\
\text { diastereomer peak 1 }\end{array}$ & $\begin{array}{c}\text { Area \% @ 210 nm for } \\
\text { diastereomer peak 2 }\end{array}$ \\
\hline $\begin{array}{c}\text { Lamivudine } \\
\text { standard }\end{array}$ & $99.96 \%$ & - & $0.04 \%$ & - \\
\hline $\begin{array}{c}\text { Lamivudine 1 } \\
\text { synthesized }\end{array}$ & $98.84 \%$ & $0.41 \%$ & $0.31 \% \%$ & $0.43 \%$ \\
\hline
\end{tabular}

\section{References:}

1. Rozwadowska, M.D.; Sulima, A.; Gzella, A. Synthesis, crystal structure and oxidation of (R)(+)-8,9-dimethoxy-6,10b-dihydro-5H-thiazolo[2,3-a]isoquinolin-3-one. Tetrahedron:Asymmetry, 2002, 13, 2329-2333.

2. Goodyear, M.D.; Dwyer, P.O.; Hill, M.L.; Whitehead, A.J.; Hornby, R.; Hallet, P. Process for the Diastereoselective Synthesis of Nucleoside Analogues. US6051709, 2000 
${ }^{1} \mathrm{H}$ NMR (600 MHz, $\left.\mathrm{CDCl}_{3}\right)$ of compound 8

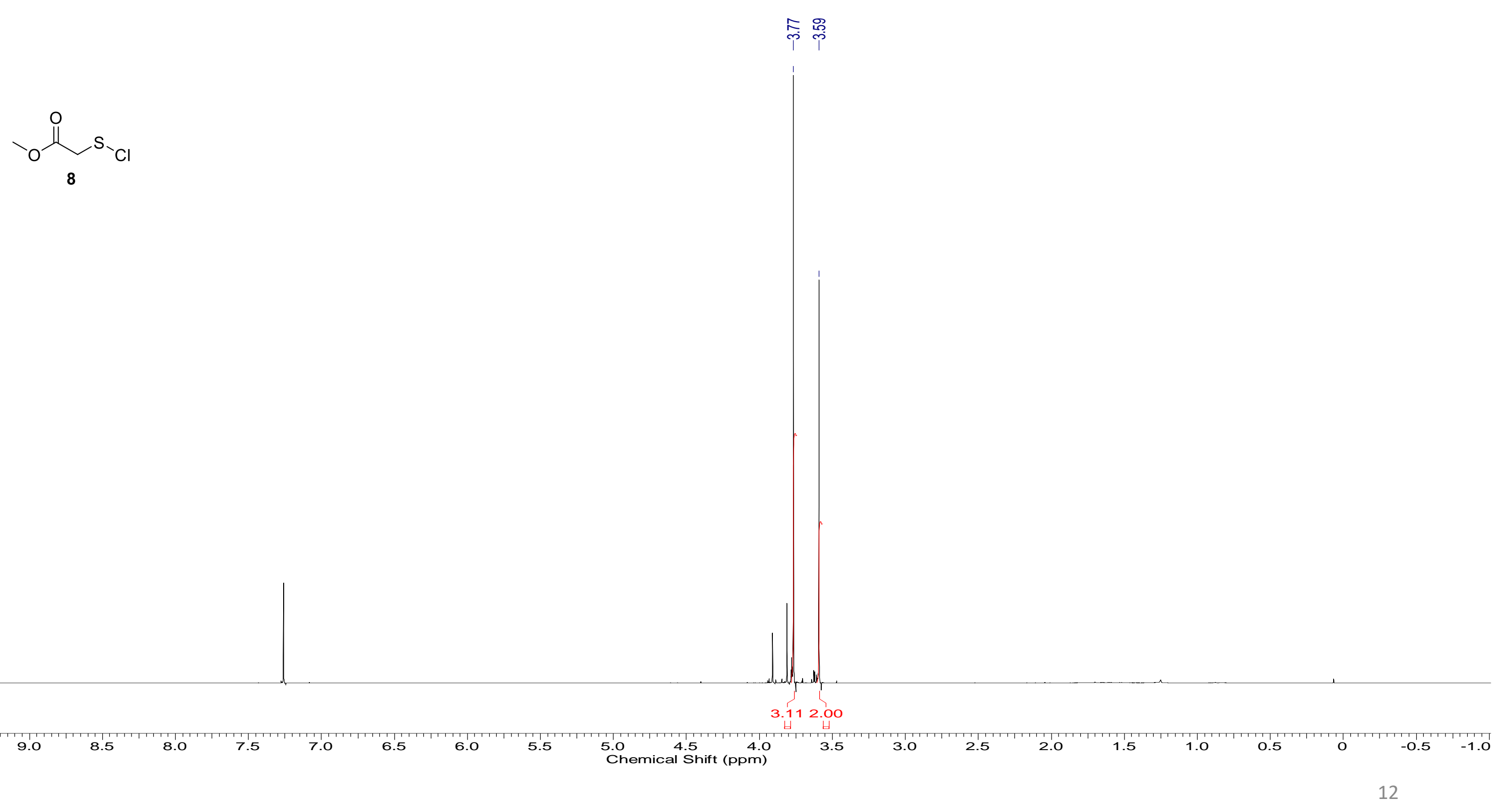


${ }^{13} \mathrm{C}$ NMR (150 MHz, $\mathrm{CDCl}_{3}$ ) of compound 8

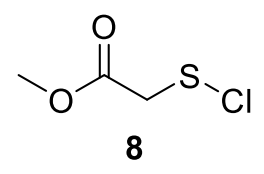


${ }^{1} \mathrm{H}$ NMR (600 MHz, $\mathrm{CDCl}_{3}$ ) of compound 10

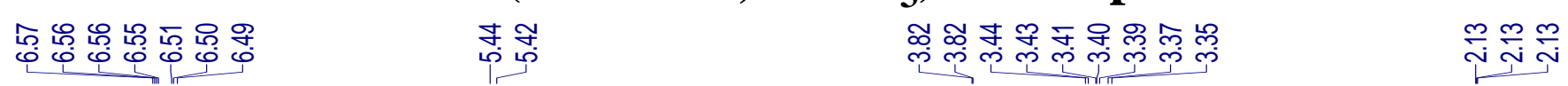

$\overbrace{C l}^{O} \sim_{O A C}^{C l}$

10
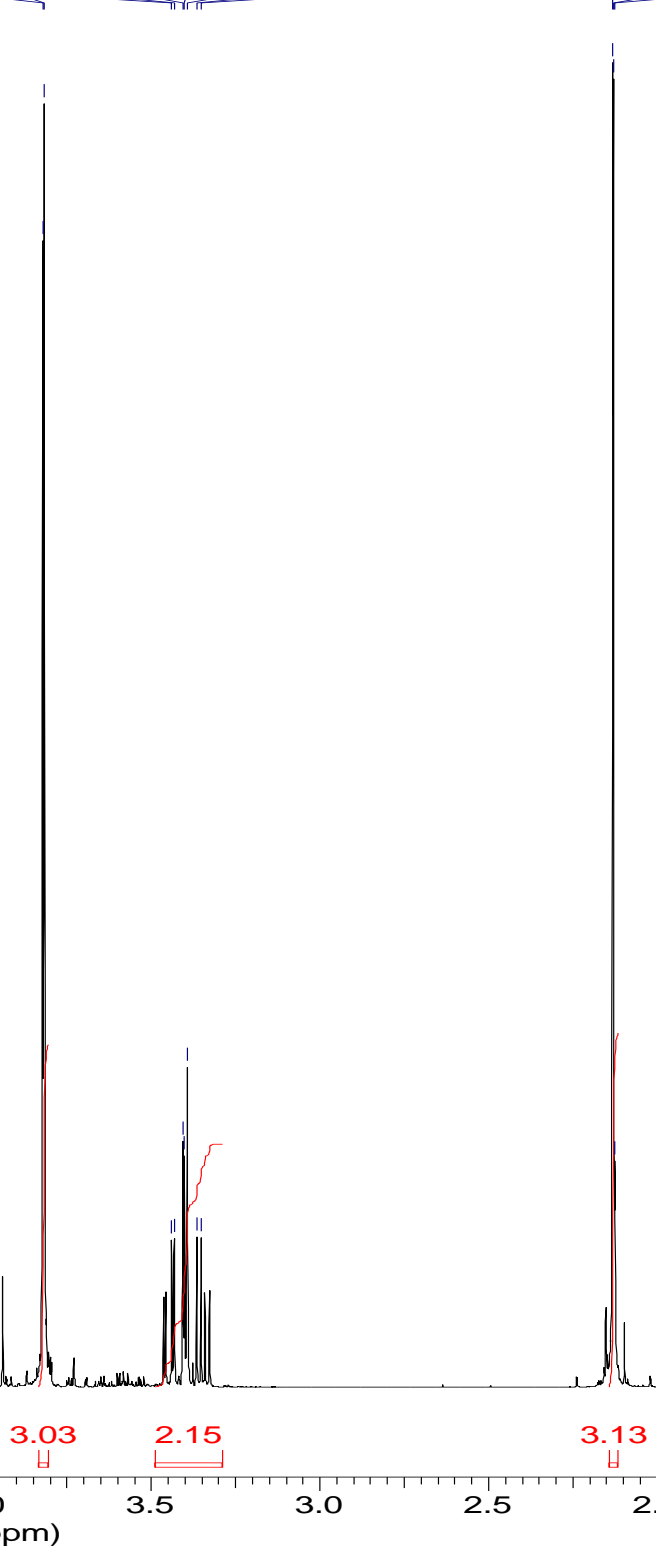

3.13 
${ }^{13} \mathrm{C}$ NMR (150 $\left.\mathrm{MHz}, \mathrm{CDCl}_{3}\right)$ of compound 10<smiles>COC(=O)C(Cl)SCC(Cl)OC(C)=O</smiles>
10 
${ }^{1} \mathrm{H}$ NMR (Screening) (600 MHz, $\left.\mathrm{CDCl}_{3}\right)$ of compound 10<smiles>COC(=O)C(Cl)SCC(Cl)OC(C)=O</smiles>

\section{0}

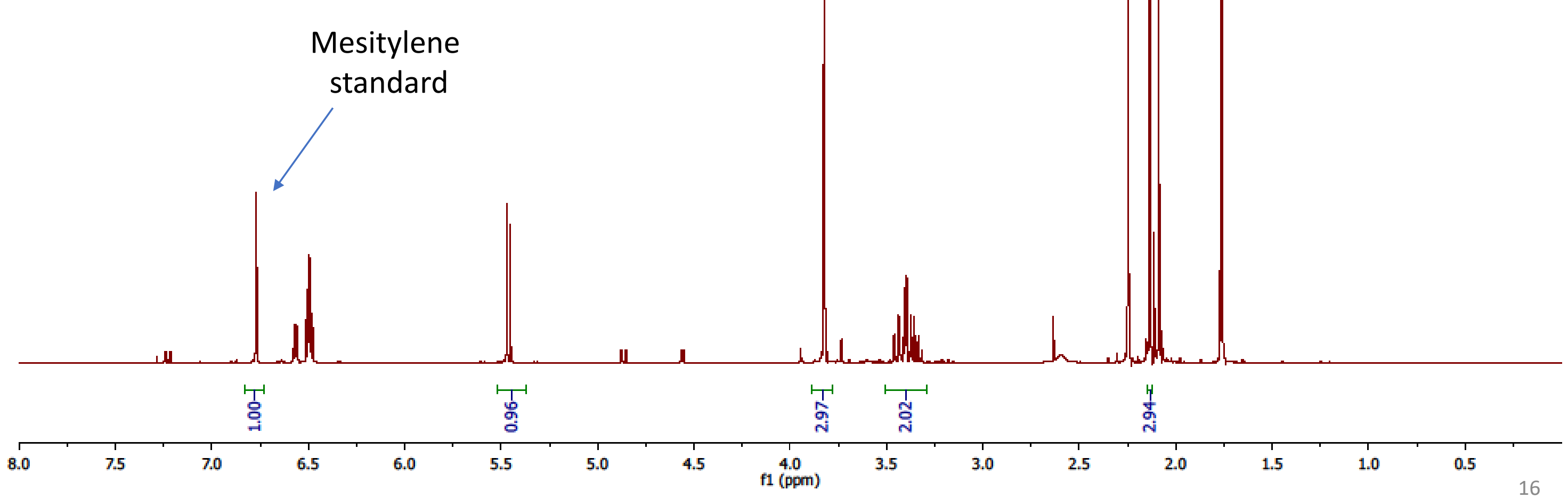


${ }^{1} \mathrm{H}$ NMR (600 MHz, $\mathrm{CDCl}_{3}$ ) of compound 12<smiles>CC(C)[C@H]1CC[C@@H](C)C[C@H]1OC(=O)CS</smiles>

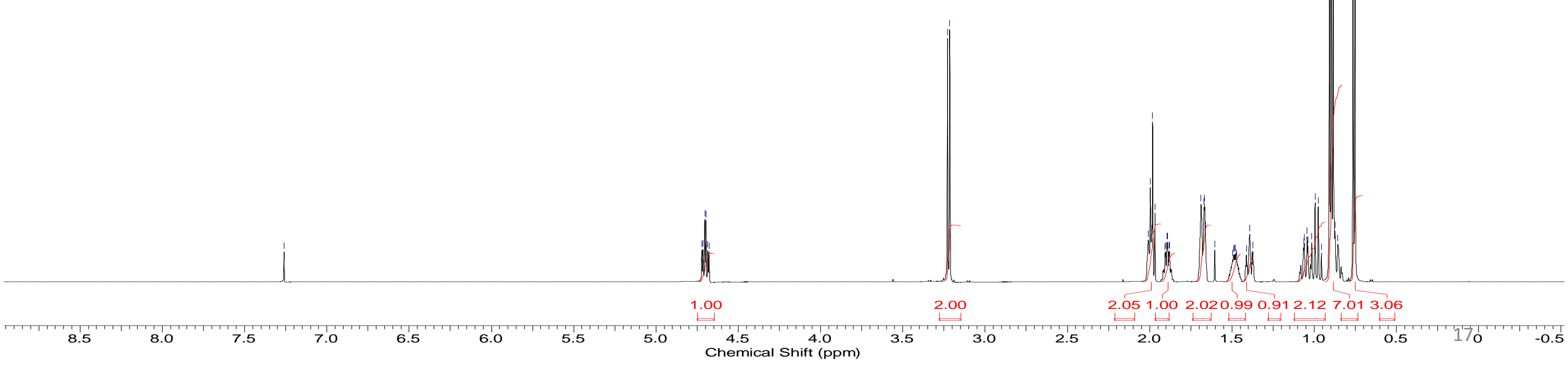


${ }^{13} \mathrm{C}$ NMR (150 MHz, $\left.\mathrm{CDCl}_{3}\right)$ of compound 12

$\underset{2}{\stackrel{2}{0}}$

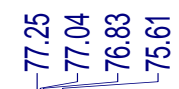

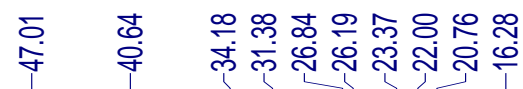<smiles>CC1CCC(C(C)C)C(OC(=O)CS)C1</smiles>

12 


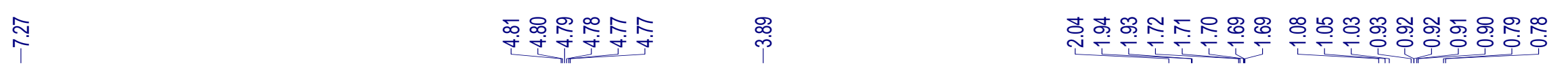<smiles>CC(C)[C@H]1CC[C@@H](C)C[C@H]1OC(=O)CSCl</smiles> 
${ }^{13} \mathrm{C}$ NMR $\left(150 \mathrm{MHz}, \mathrm{CDCl}_{3}\right)$ of compound 13

$\frac{0}{9}$<smiles>CC1CCC(C(C)C)C(OC(=O)CSCl)C1</smiles>

o

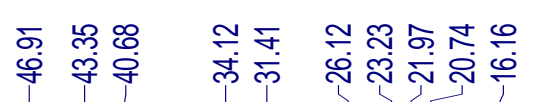




\section{${ }^{1} \mathrm{H}$ NMR (600 MHz, $\left.\mathrm{CDCl}_{3}\right)$ of compound 15}

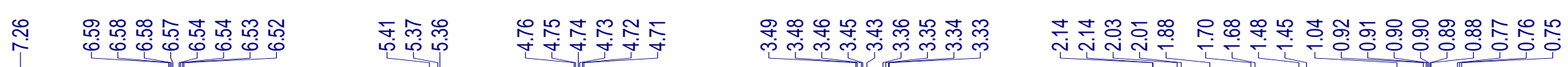<smiles>CC(=O)OC(Cl)CSC(Cl)C(=O)OC1C[C@@H](C)CC[C@H]1C(C)C</smiles>

15

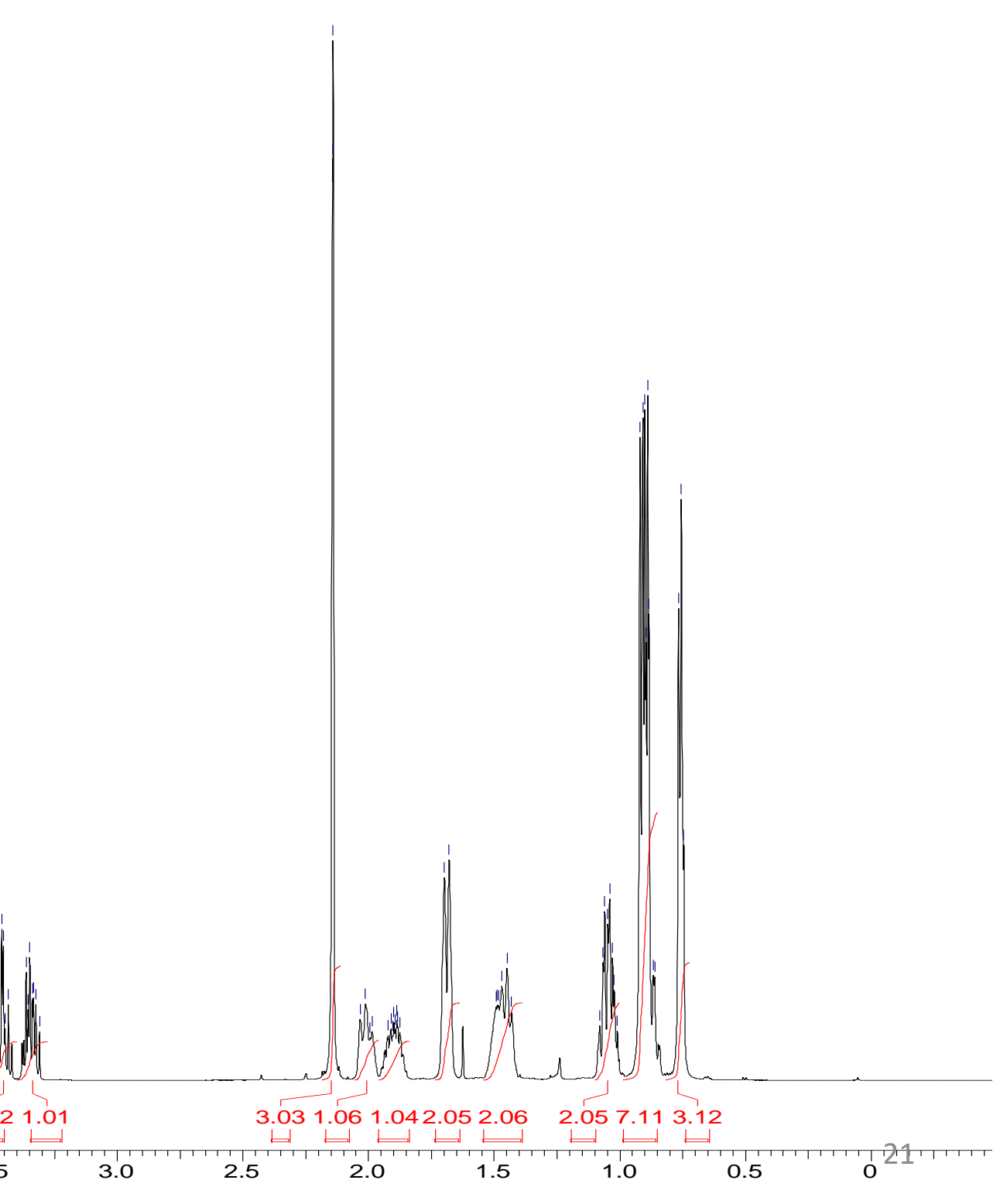


${ }^{13} \mathrm{C}$ NMR (150 MHz, $\left.\mathrm{CDCl}_{3}\right)$ of compound 15

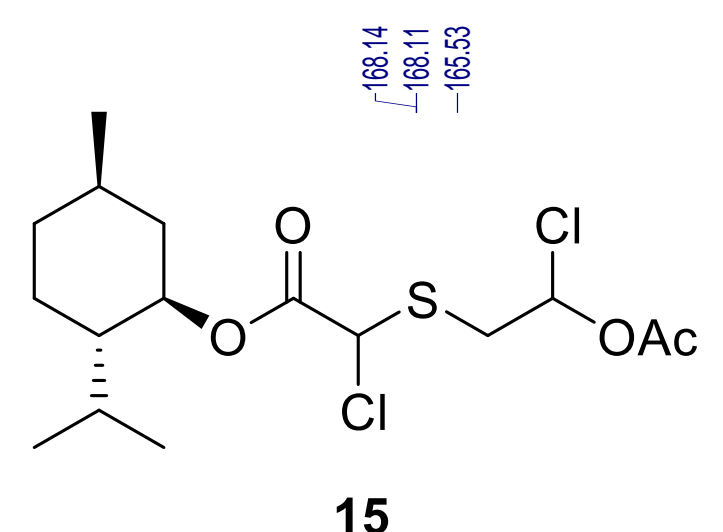

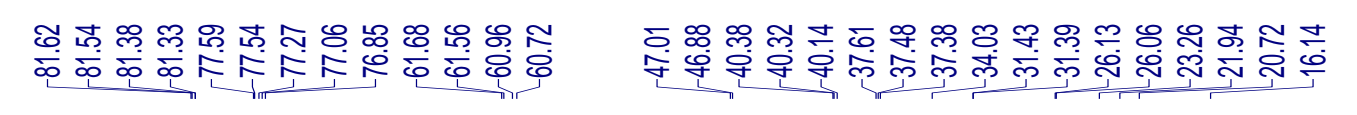




\section{${ }^{1} \mathrm{H}$ NMR (600 MHz, $\left.\mathrm{CDCl}_{3}\right)$ of compound 4}

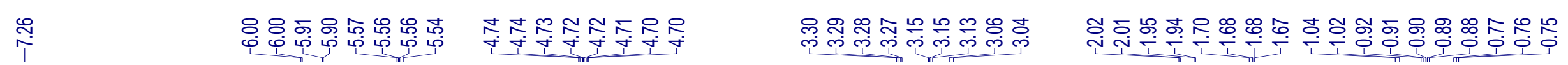<smiles>CC1CC[C@H](C(C)C)C(OC(=O)[C@H]2OC(O)CS2)C1</smiles>

4 
${ }^{13} \mathrm{C}$ NMR (150 MHz, $\left.\mathrm{CDCl}_{3}\right)$ of compound 4

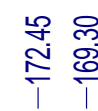

高家

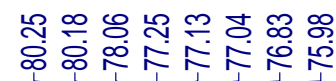

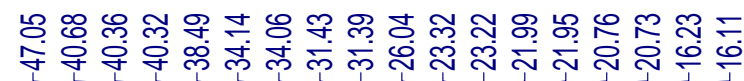<smiles>CC(C)[C@H]1CC[C@@H](C)C[C@H]1OC(=O)[C@H]1OC(O)CS1</smiles>

4 
${ }^{1} \mathrm{H}$ NMR (600 MHz, $\mathrm{CDCl}_{3}$ ) of compound 4 (Commercial)

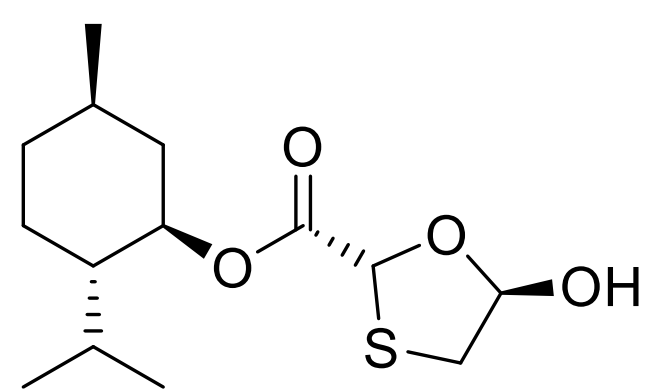

4

(Commercial sample) 
${ }^{13} \mathrm{C}$ NMR (150 MHz, $\mathrm{CDCl}_{3}$ ) of compound 4 (Commercial)

荵畧

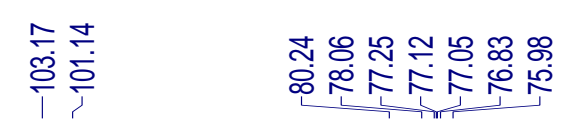

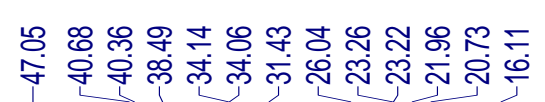<smiles>CC(C)[C@H]1CC[C@@H](C)C[C@H]1OC(=O)[C@H]1O[C@@H](O)CS1</smiles>

4

(Commercial sample) 


\section{${ }^{1} \mathrm{H}$ NMR (600 MHz, DMSO-d 6 ) of compound 3}

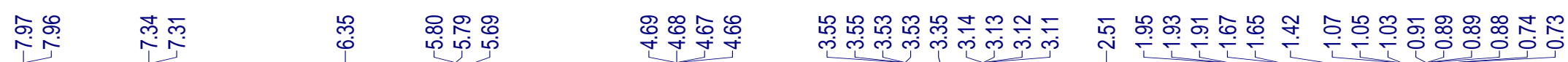

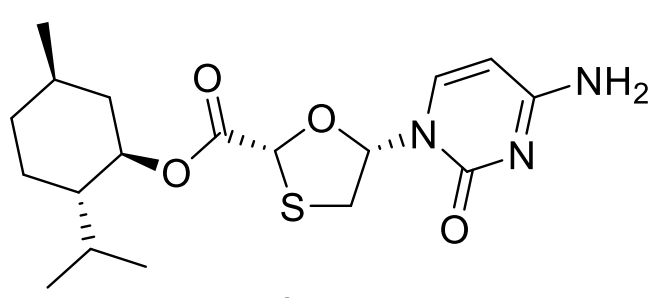

3

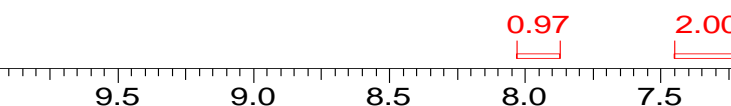

$0.94 \quad 1.130 .95$

0.99

$1.01 \quad 0.98$

2.022 .042 .022 .047 .123 .17

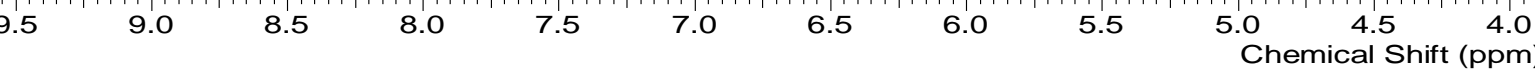


${ }^{13}$ C NMR (150 MHz, DMSO-d $)$ of compound 3

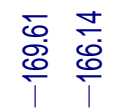

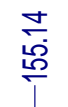
旁
㺃
옷 总
心

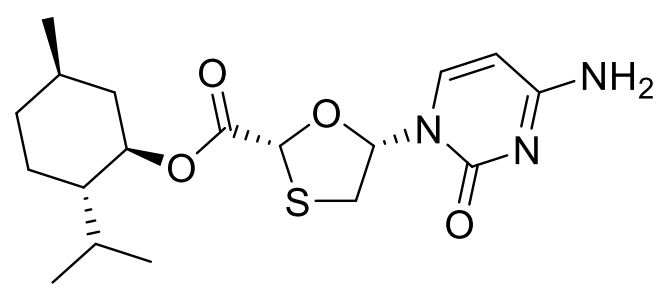

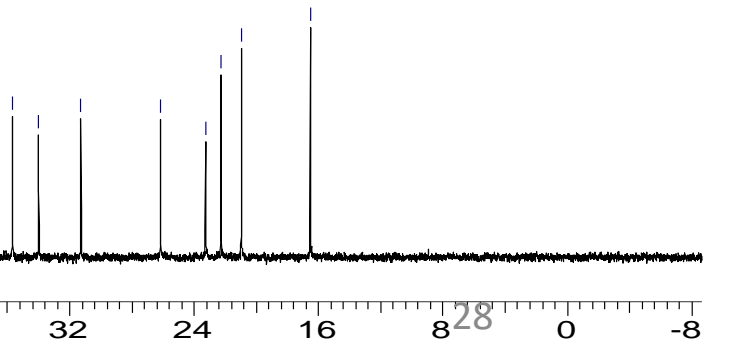


${ }^{1} \mathrm{H}$ NMR (600 MHz, CD $\left.\mathrm{OD}\right)$ of compound 1

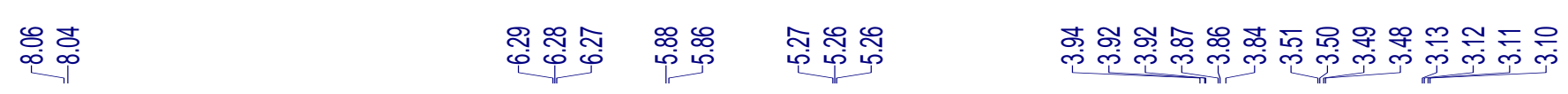<smiles>Nc1ccn([C@H]2CS[C@@H](CO)O2)c(=O)n1</smiles>

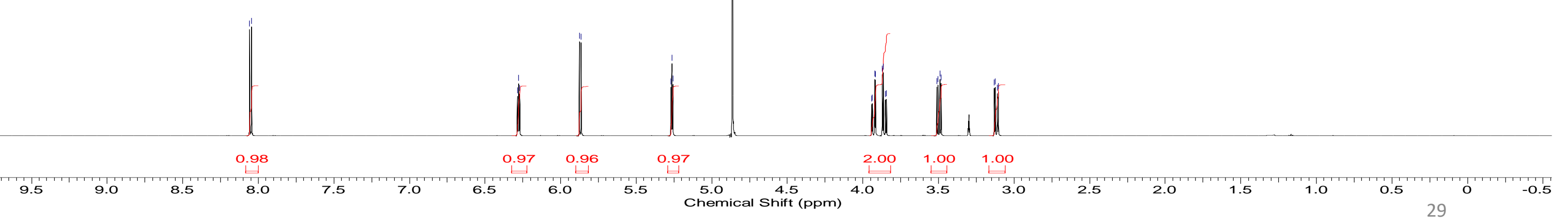


${ }^{13} \mathrm{C}$ NMR (150 MHz, $\left.\mathrm{CD}_{3} \mathrm{OD}\right)$ of compound 1

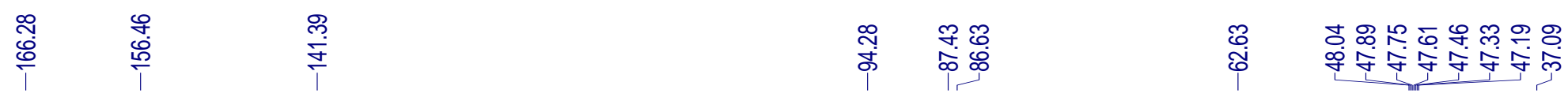

$\mathrm{HO}_{\mathrm{S}}^{\prime \prime \cdots} \mathrm{C}_{1}^{\mathrm{O}} \prod_{\mathrm{O}}^{\mathrm{N}} \mathrm{N}^{\mathrm{N} \mathrm{N}_{2}}$

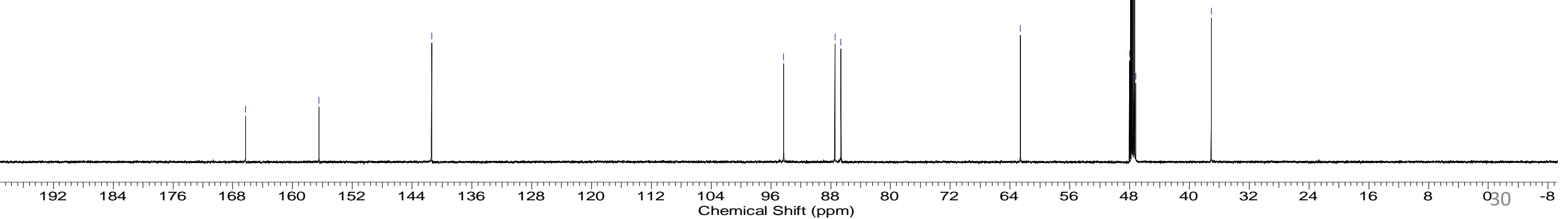


${ }^{1} \mathrm{H}$ NMR $\left(600 \mathrm{MHz}, \mathrm{CDCl}_{3}\right)$ of compound 19

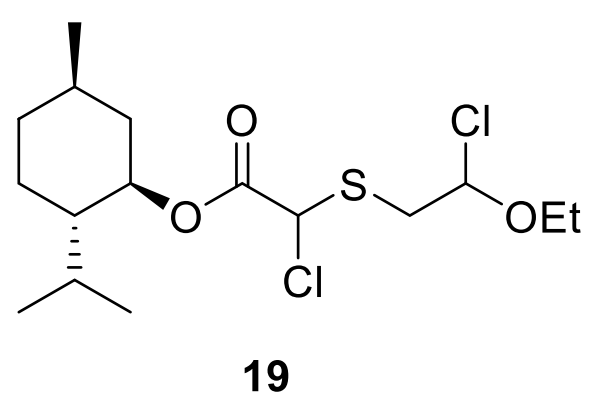

19

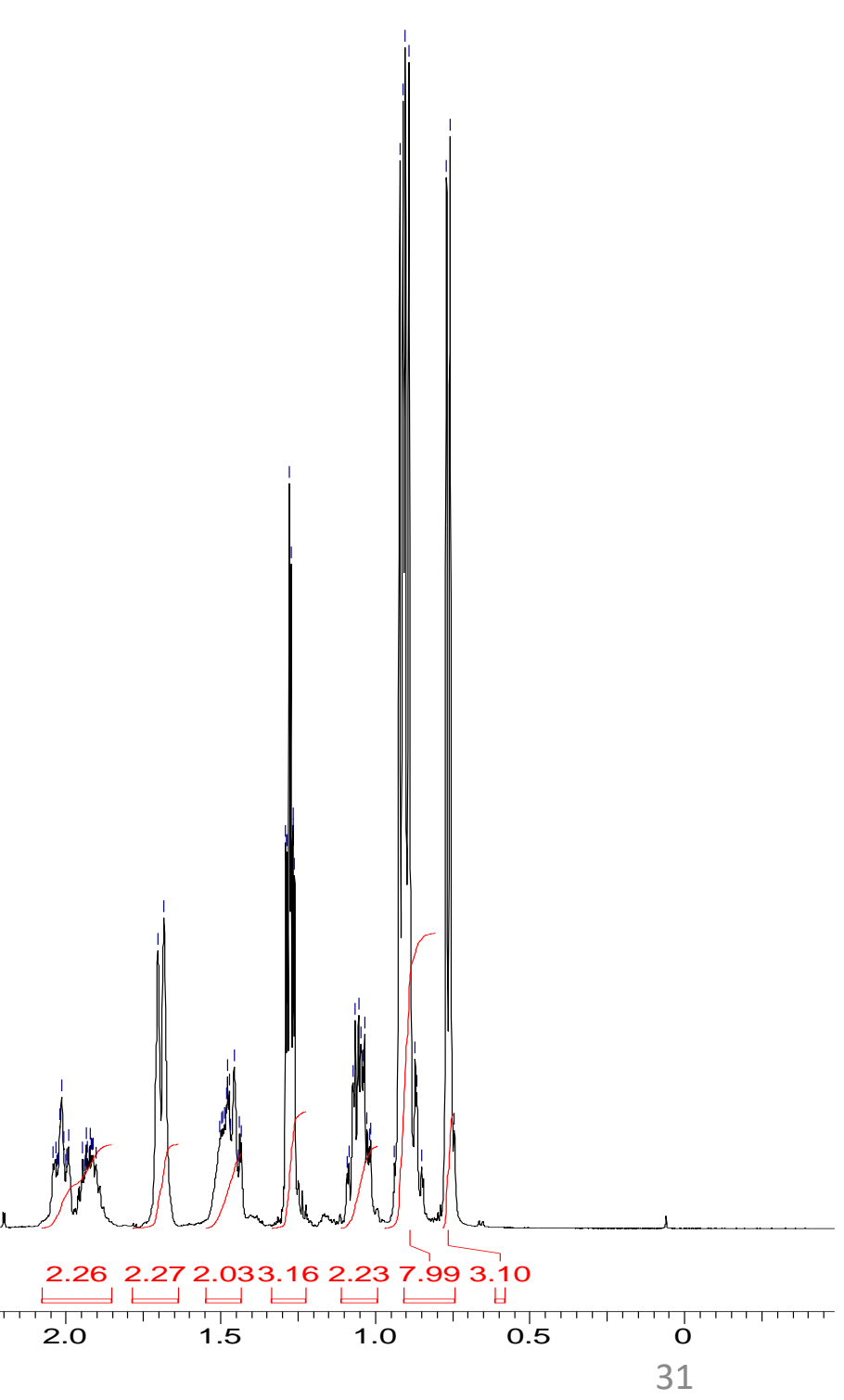


${ }^{13} \mathrm{C}$ NMR (150 MHz, $\mathrm{CDCl}_{3}$ ) of compound 19

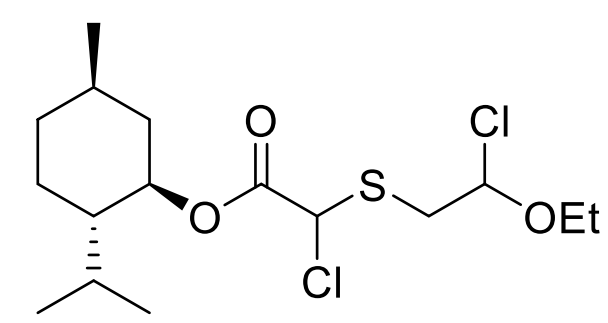

19

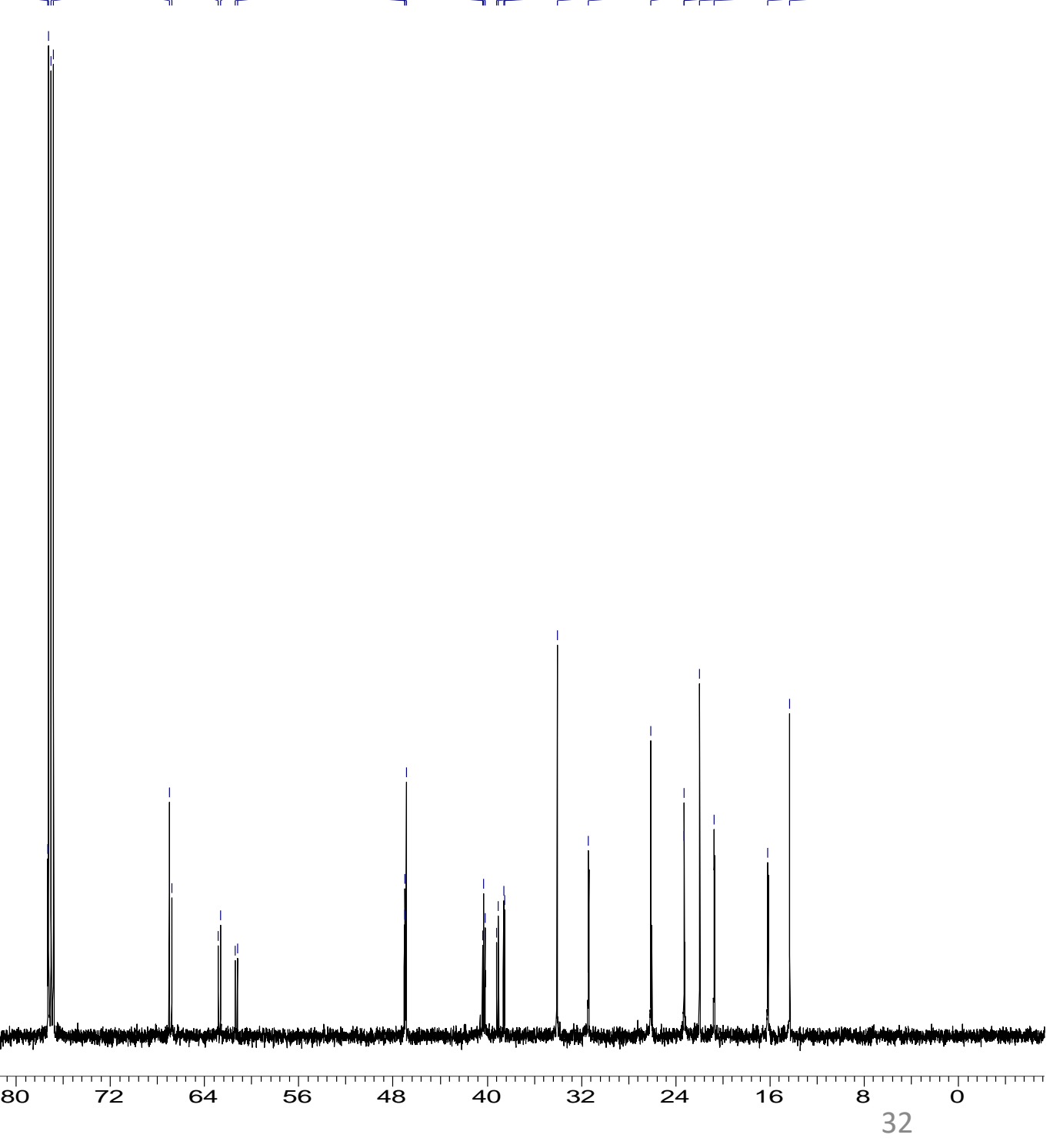




\section{${ }^{1} \mathrm{H}$ NMR (600 MHz, $\left.\mathrm{CDCl}_{3}\right)$ mixture of compounds $17 \& 20$}

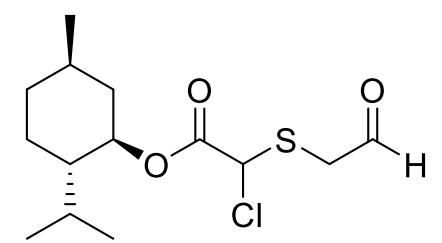

17

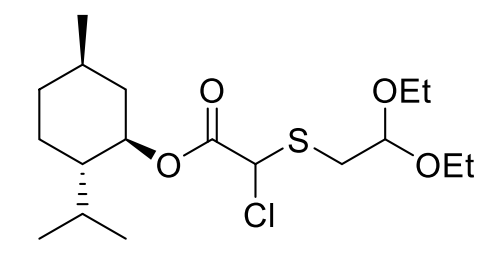

20
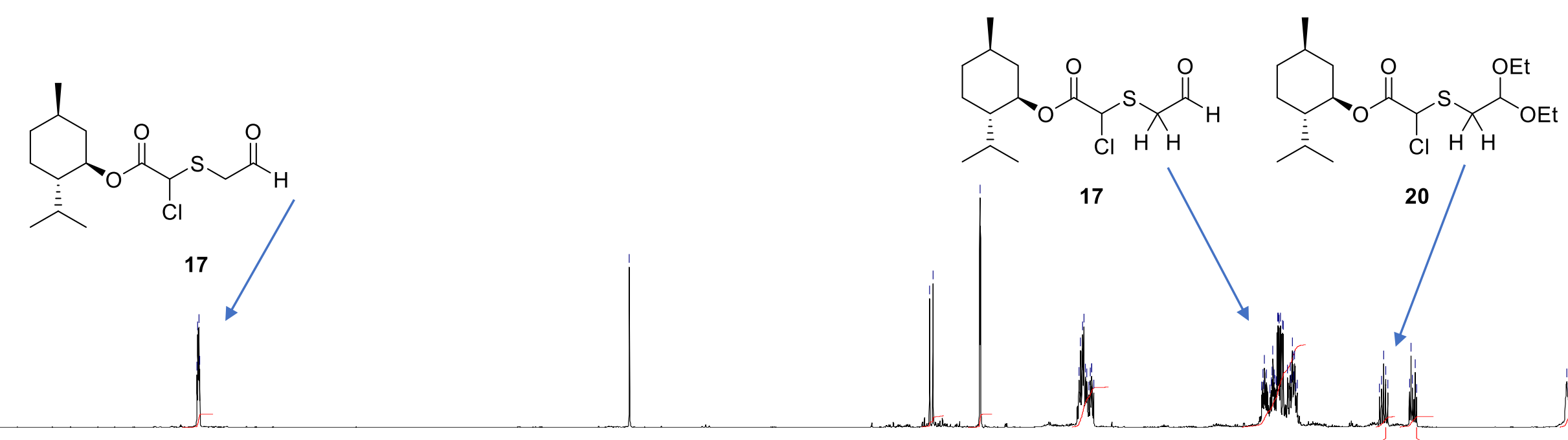

0.32 
${ }^{1} \mathrm{H}$ NMR (600 MHz, $\mathrm{CDCl}_{3}$ ) of compound 4 with mesitylene as standard (from Ethyl Vinyl Ether route)
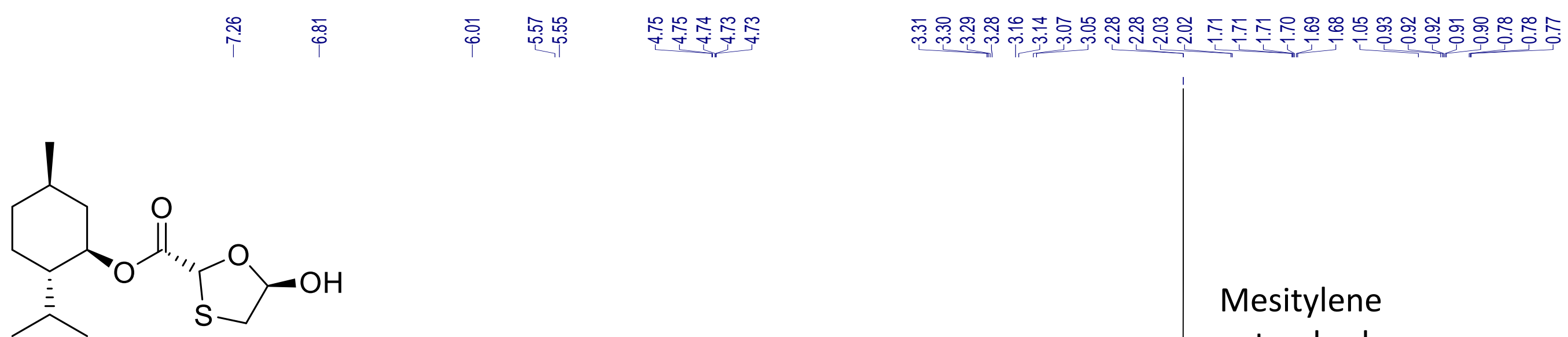

Mesitylene

4 standard

Mesitylene

standard 
${ }^{1} \mathrm{H}$ NMR (600 MHz, $\mathrm{CDCl}_{3}$ ) of compound 4 with mesitylene as standard (from Vinyl Acetate route)

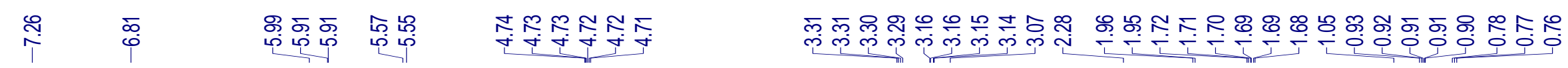

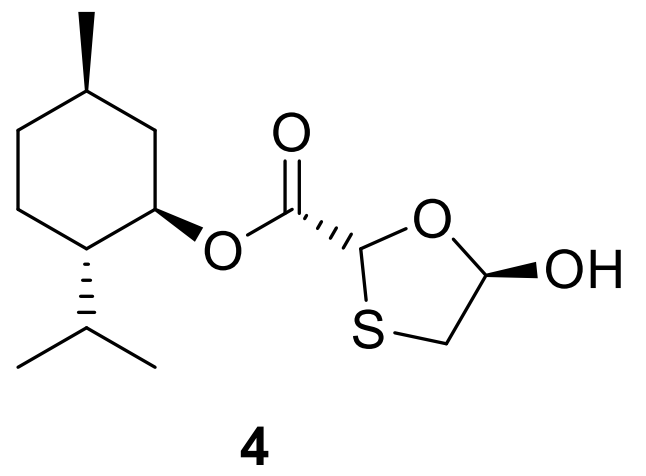

\section{Mesitylene} standard

4

Mesitylene

standard 